\title{
Molecular Studies on Infectious Bronchitis Virus Isolated from Broiler Chickens in
} Damietta Governorate, Egypt

\author{
Elsayed M. Awad ${ }^{1 *}$, Abdel Satar Arafa ${ }^{2}$, Ayman H. El-Deeb ${ }^{3}$, Ahmed A. El-Sanousi ${ }^{3}$ \\ ${ }^{1}$ Animal Health Research Institute, Damietta branch, Damietta, Egypt \\ ${ }^{2}$ National Laboratory for Veterinary Quality Control on Poultry Production, Animal Health \\ Research Institute, Dokki, Giza, Egypt \\ ${ }^{3}$ Virology Department, Faculty of Veterinary Medicine, Cairo University, Giza, Egypt
}

Article History: Received: 1/6/2016 Received in revised form: 13/8/2016 Accepted: 15/9/2016

\section{Abstract}

Fifty-two samples of tracheal swabs and organs were collected from broiler chickens at different districts from Damietta Governorate during December 2012 to August 2014. The samples were collected from chicken farms suffered from respiratory signs, diarrhea and high mortality. Thirtysix samples tested positive for IBV infection when screened by real time quantitative polymerase chain reaction (RT-qPCR). Seven of them were subjected for further isolation and characterization of the virus. The seven selected IBV isolates were propagated in embryonated chicken eggs (ECE) and were confirmed using PCR amplification of the partial sequence of the S1 spike gene. The amplified products were sequenced and the phylogenetic analysis was performed. The seven IBV viruses were closely related to each other with $94-100 \%$ nucleotide identity and clustered within the same group with IBV/Eg/CLEVB-2/IBV/012 and Eg/12120s/2012 strains (variant 2-like strain), while their identity with the vaccinal strains used in Egypt was ranged from 67-91\%, particularly D274 (89\%-91\%). These results indicated the complexity of IBV control in relation to the current vaccination programs in Damietta.

Keywords: Infectious Bronchitis Virus, RT-PCR, Sp1 gene, Phylogenetic Analysis

\section{Introduction}

Infectious bronchitis (IB) is an extremely contagious viral infection that induces serious economic losses of the poultry industry around the world. The respiratory manifestation of the disease is the most common among clinical cases and it is characterized by tracheal rales, coughing, and sneezing [1]. The infection may spread to the reproductive and renal systems, leading to oviduct and kidney lesions in layers. Infectious bronchitis virus (IBV) is a Coronavirus belonging to Family Coronaviridae (Genus Coronavirus, group III) [2]. The virus is single stranded, nonsegmented, positive sense RNA virus with an envelope of approximately $120 \mathrm{~nm}$ in diameter [3-5].

The genome of IBV is $27 \mathrm{kB}$ length and encodes for four structural proteins; the spike (S) glycoprotein, the membrane (M) glycoprotein, the nucleocapsid (N) phosphoprotein, and the envelope (E) protein
$[4,6]$. The $\mathrm{S}$ protein is the structural protein of the spikes, which are essential for viral attachment to the cells, fusion of the viral envelop with the host cell membrane, and neutralizing antibodies induction [7]. The S1 and $S 2$ portions of the $S$ protein result from the cleavage of the spike precursor propolypeptide [8]. In the S1 subunit, three hypervariable regions (HVRs) have been identified [9,10]. Haemagglutination-inhibiting and most of the virus-neutralizing antibodies are induced by $\mathrm{S} 1$ [11]. Therefore, S1 gene analysis is mainly used for molecular characterization of IBV.

In different Egyptian poultry farms, Massachusetts D3128, D274, D-08880 and 4/91 genotypes of IBV strains have been detected [12]. In 2001, the Egyptian variant, Egypt/BeniSuef/01 which was closely related to the Israeli variant strain was isolated from different poultry farms [13]. Selim et al. [14] reported the isolation of the Egyptian variants 
$\mathrm{Eg} / 12120 \mathrm{~s} / 2012$ and $\mathrm{Eg} / 1265 \mathrm{~B} / 2012$ from broiler and layer chicken farms in Egypt during 2013. Accordingly, molecular epidemiological studies are very important for genotyping of IBV field strains.

The main objective of the study was to determine the prevalence and diversity of IBV genotypes at broiler chicken farms in Damietta Governorate.

\section{Material and Methods}

\section{Sample collection}

In this study, 52 pooled samples were collected from 52 broiler chicken farms located at different districts of Damietta Governorate, Egypt. The investigated broiler farms showed respiratory signs, diarrhea and high mortality during surveillance from December 2012 to August 2014. Five tracheal swabs/each case and organs (trachea, lungs and kidneys) were collected from dead birds. Out of 52 broiler farms 18 were vaccinated against IBV with commercial live attenuated H120 strain vaccines.

\section{Detection of IBV by real time RT-PCR}

Real-time reverse transcription-polymerase chain reaction (RT-qPCR) was carried out for the direct detection of IBV in the clinical samples. The viral RNA was extracted using QiaAmp viral RNA mini kit (Qiagen, Germany) following the manufacturer's guidelines. The reaction was performed using Qiagen one step RT-PCR Kit (Qiagen, GmbH, Hilden, Germany). Amplification of the specific target was conducted using the forward primer IBV5_GU391, 5'-AC GTATGACTACCCGCAGTATTCA-3', reverse primer IBV5_GL533, 5'AGACCAGCCACCATGATTGC-3' and probe IBV5_G,

FAMCACCACCAGAACCTGTCACC TCBHQ1-3' [15]. Seven positive samples were then selected for further virus isolation and characterization based on the district locality. The selected isolates were not vaccinated with live attenuated vaccine.

\section{Virus isolation and propagation}

The virus was isolated from seven RT-PCR positive samples. The supernatant was inoculated into 10-day-old embryonated specific pathogen free (SPF) chicken eggs (Komoshim, Fayuom). Procedures were performed according to OIE terrestrial manual [16]. Embryos were examined for curling and dwarfism after harvesting of the allantoic fluids [17]. Each sample was subjected to three serial blind passages to induce the IBV characteristic lesions in the chicken embryos.

\section{Genetic characterization of hypervariable regions (HVRs) of Spike 1 (S1) gene}

The HVRs of S1 gene were amplified by conventional PCR using Qiagen one step RTPCR Kit (Qiagen, GmbH, Hilden, Germany). The used primers were IBV-S1-F 5'CACTGGTAATTTTTCAGATGG-3' and IBVS1-R 5'-CAGATTGCTTACAACCACC-3' [18]. The reaction conditions were reverse transcription at $50^{\circ} \mathrm{C}$ for $30 \mathrm{~min}$, primary denaturation at $95^{\circ} \mathrm{C}$ for $15 \mathrm{~min}$ followed by 40 cycles of denaturation at $95^{\circ} \mathrm{C}$ for $30 \mathrm{sec}$, annealing at $54^{\circ} \mathrm{C}$ for $45 \mathrm{sec}$ and extension at $72^{\circ} \mathrm{C}$ for $2 \mathrm{~min}$, and finally a final extension at $72^{\circ} \mathrm{C}$ for $10 \mathrm{~min}$. RT-PCR product was visualized by Electrophoresis in $1.5 \%$ agarose in IX TAE, ethidium bromide was added to a concentration of $0.5 \mu \mathrm{g} / \mathrm{mL}$ for nucleic acid visualization. A positive control that was obtained from known positive reference sample from National Laboratory for Veterinary Quality Control on Poultry Production (NLQP) deposits was also run in the reaction.

\section{Sequencing}

Amplicons of the proper molecular size were purified using QIAquick PCR Product extraction kit (Qiagen Inc. Valencia CA) following the manufacturer guidelines. Sequencing was then carried out using Big dye Terminator V3.1 cycle sequencing kit (PerkinElmer, Foster City, CA.USA, cat. no. 4336817) in an Applied Biosystems 3130 genetic analyzer (Hitachi, Japan), with 3130 Genetic Analyzer Capillary Array, 3130 Running Buffer, BigDye ${ }^{\circledR}$ Terminator v3.1 5X Sequencing Buffer, Hi-DiTM Formamide. Submission of the nucleotide sequences to GenBank for getting accession numbers was carried out. 
Table 1: The IBV reference strains published in Gene Bank used in this study

\begin{tabular}{llll}
\hline IBV strain & Accession number & IBV strain & Accession number \\
\hline UK/4/91 & AF093794 & Egypt/F/03 & DQ487085 \\
D274 & X15832 & IBV/Egypt/Zag/07-01 spike & EU368592 \\
H120 & M21970 & Sul-01-09 & GQ281656 \\
Ma5 & AY561713 & IS-885 & AY279533 \\
M41 & AY561711 & IS-1494-06 & EU780077 \\
IBV-strain-NGA-310-2006 & FN182278 & Mans-5 sp1 & KF856876 \\
IBV/Eg/CLEVB-2/IBV/012 & JX173488 & Mans-2 sp1 & KF856873 \\
Eg/12120s/2012 & KC533684 & IBV/Eg/CLEVB-1/IBV/012 & JX173489 \\
CR88121 & JN542567 & Variant 2 & AF093796 \\
Eg/1265B/2012 & KC533682 & strain NGA/310/2006 & FN182278 \\
QXIBV & AF193423 & Connecticut 46 & DQ487085 \\
\hline
\end{tabular}

\section{Sequence and phylogenetic analysis}

Alignment of the sequences was carried out by the Clustal W method using MegAlign module of DNAStar software (Lasergene version 7.2, DNASTAR, Madison, WI, USA). The nucleotide sequences were compared with IBV sequences available in GenBank and commonly used vaccinal strains (Table 1). Sequence identities were calculated using DNAStar software [19]. Construction of the phylogenetic tree of the aligned sequences by neighbor-joining method in MEGA5 (www.megasoftware.net) was performed. The tree topology was evaluated by 500 bootstrap analysis [20]. The deduced amino acid sequences were determined to identify the pathotype of the isolated IBV strains. The Maximum Composite Likelihood method was used to compute the evolutionary distances (the units of the number of base substitutions per site). Evolutionary analyses were conducted in MEGA5.

Table 2: The result of real-time RT-PCR in vaccinated and non-vaccinated flocks

\begin{tabular}{|c|c|c|c|c|c|}
\hline \multirow{2}{*}{ Serial } & \multirow{2}{*}{ district } & \multirow{2}{*}{$\begin{array}{l}\text { Number of } \\
\text { flocks }\end{array}$} & \multirow{2}{*}{$\begin{array}{l}\text { Total no. of positive } \\
\text { flocks }\end{array}$} & \multicolumn{2}{|c|}{ Results in relation to vaccination against IB } \\
\hline & & & & $\begin{array}{c}\text { Positive/Total vaccinated } \\
(\%)\end{array}$ & $\begin{array}{l}\text { Positive /Total not } \\
\text { vaccinated }\end{array}$ \\
\hline 1 & Damietta & 13 & 10 & $3 / 4$ & $7 / 9$ \\
\hline 2 & Fariskour & 18 & 12 & $2 / 6$ & $10 / 12$ \\
\hline 3 & Kafr saad & 11 & 8 & $2 / 4$ & $6 / 7$ \\
\hline \multirow[t]{2}{*}{4} & Elzarka & 10 & 6 & $2 / 4$ & $4 / 6$ \\
\hline & Total & 52 & 36 & $\begin{array}{c}9 / 18 \\
(50 \%)\end{array}$ & $\begin{array}{c}27 / 34 \\
(79.4 \%) \\
\end{array}$ \\
\hline
\end{tabular}




\section{Results}

Out of the examined 52 farms, 36 were positive for IBV by RT-qPCR using specific primers and probes (Table 2). According to the locality of the positive districts, seven isolates were selected for further molecular characterization.

After three blind passages of the seven IBV isolates, the inoculated embryos showed obvious curling and dwarfing with subcutaneous hemorrhages. These lesions were characteristic for the seven tested samples.

The selected seven isolates were positive for hypervariable regions of $\mathrm{S} 1$ gene by the amplification of $500 \mathrm{bp}$ amplicon (Figure 1).
Sequencing and alignment analysis of such region in the seven strains showed 94-100\% nucleotide identity when they were compared together. In addition, when the seven strains were compared with other vaccine strains used in Egypt (M41, H120, Ma5, 4/91, CR88 and D274), the nucleotide identity ranged from 6791\% (Table 3).

Figure 2 shows the analysis of the phylogenetic tree of the seven selected strains. All of the sequences are grouped together with Eg/1265B/2012 and Eg/12120s/2012 Egyptian strains of Variant 2-like lineage. The vaccine strain (D274) was shown to be the nearest strain to the studied strains with nucleotide identity ranged from $89-91 \%$ (Table 3).

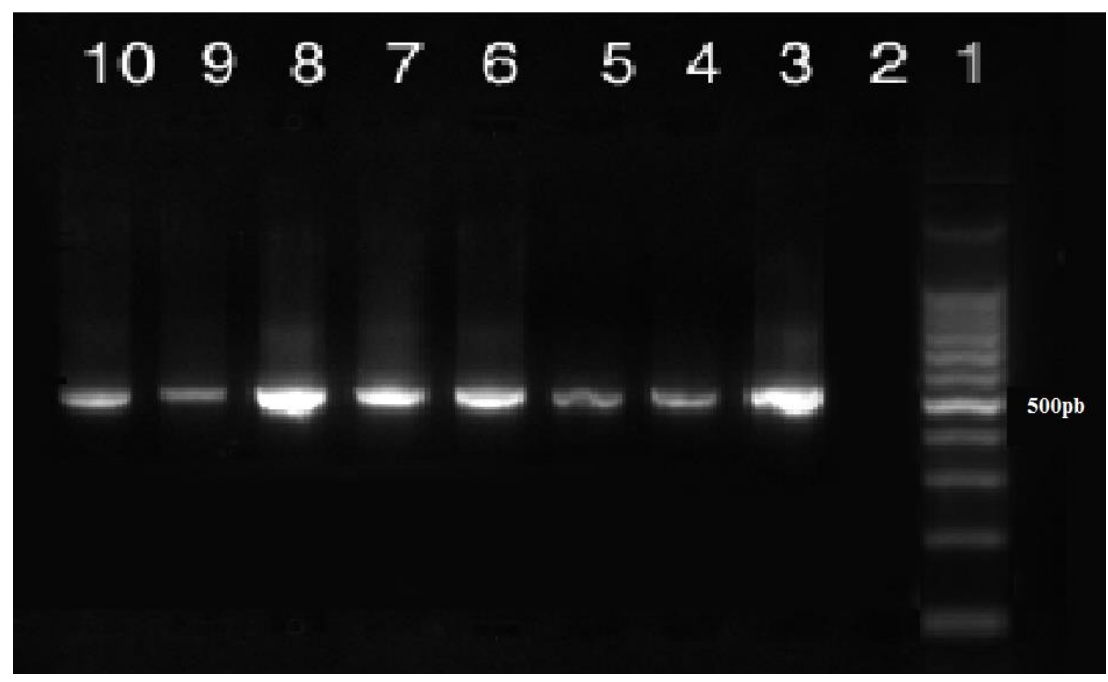

Figure 1: Gel electrophoresis of the 500 bp RT-PCR products of the selected seven isolates, Lane 1: 100 bp ladder, Lane 2: negative control, Lane 3: positive control (known positive reference sample from NLQP deposits), Lanes 4-10: the seven isolates under investigation.

\section{Discussion}

The current study is considered the first molecular record for IBV in Damietta Governorate. Fifty-two broiler chicken farms were examined by real time PCR to highlight the distribution of infection in the districts of Damietta Governorate. Out of 52 examined clinical samples, 36 were positive by real time PCR. Based on their origin, seven samples were selected for further isolation. The selected isolates were not vaccinated with live attenuated vaccine to avoid isolation of the vaccine stain.

Inoculated SPF-ECE showed typical IBV lesions as curling and dwarfing of the embryo and this agreed with the results reported before [21]. The isolates were confirmed positive by real time PCR.

Genotyping of the seven isolates was carried out using partial sequencing of $\mathrm{S} 1$ gene [22]. Relation between recent isolates and other IBV isolates circulating in the Middle 
East and with vaccine strains was conducted with phylogenetic analysis.

The sequences of the seven IBV field strains in this study (IBV-EG-Damietta1, IBVEG-Damietta2, IBV-EG-Elzarka1, IBV-EGFriskur1, IBV-EG-Friskur2, IBV-EG-
Kafrsaad1, IBV-EG-Kafrsaad2) present in the same group with Eg/1265B/2012, $\mathrm{Eg} / 12120 \mathrm{~s} / 2012$ (Figure 2). In accordance with Selim et al. [14], the vaccinal strain (D274) is found to be the nearest vaccine strain to these seven isolates.

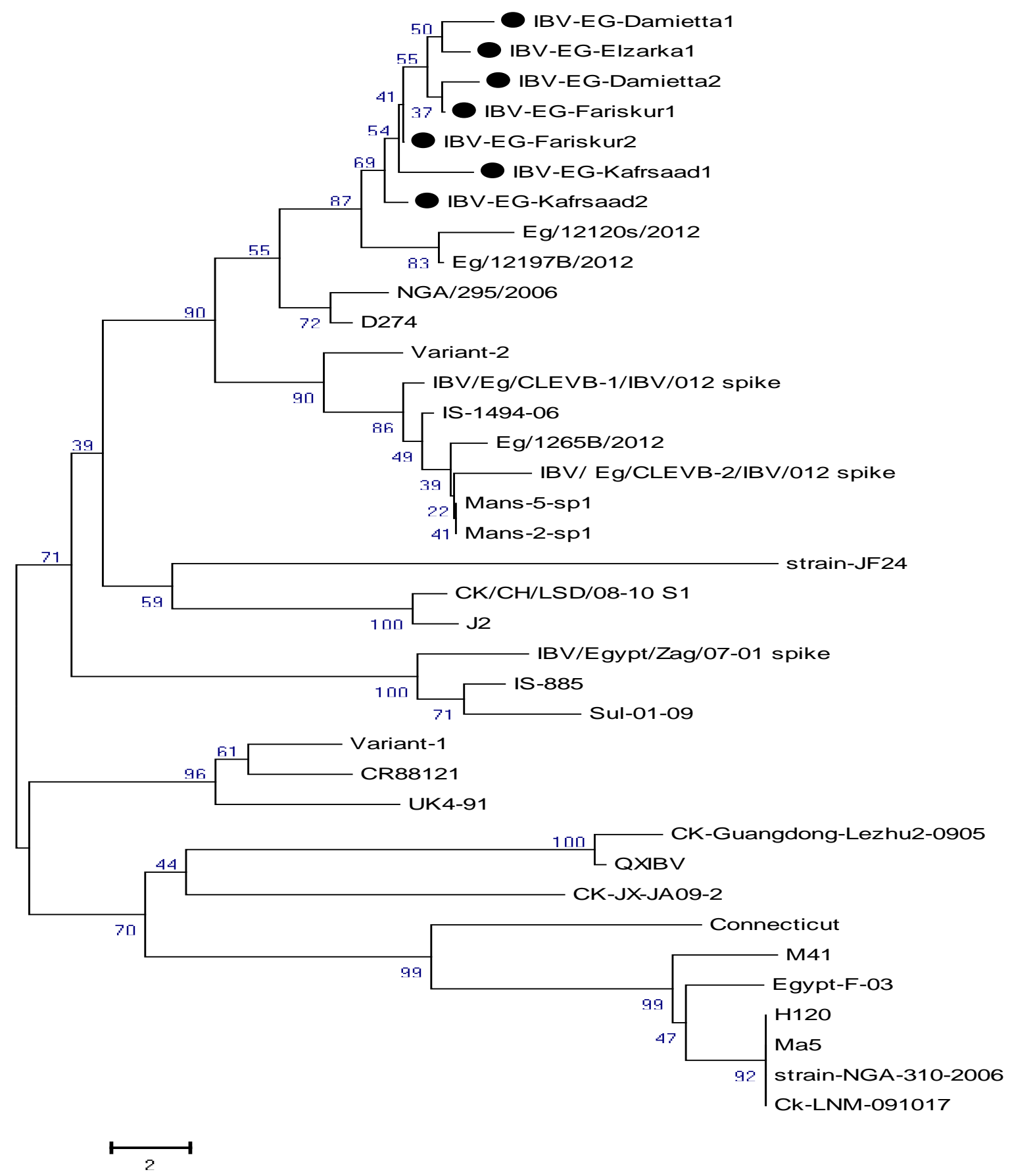

Figure 2: Phylogenetic tree of the $318 \mathrm{~b}$ fragment of the S1 nucleotide sequence of the seven Egyptian IBV isolates in this study, vaccinal strain present in Egypt and other reference IBV strains. The phylogenetic tree analysis was conducted by neighbor-joining method using bootstrap analysis (500 replications) using Mega 5 software. 
Table 3: Nucleotide identity between the seven selected isolates and Sequences of IBV reference strains published in Gene Bank

\begin{tabular}{|c|c|c|c|c|c|c|c|c|c|c|}
\hline Isolates & $\begin{array}{l}\text { Accession } \\
\text { number }\end{array}$ & country & Year & $\begin{array}{l}\text { Identity to } \\
\text { No.1 }\end{array}$ & $\begin{array}{l}\text { Identity to } \\
\text { No.2 }\end{array}$ & $\begin{array}{l}\text { Identity to } \\
\text { No.3 }\end{array}$ & $\begin{array}{l}\text { Identity to } \\
\text { No4 }\end{array}$ & $\begin{array}{l}\text { Identity to } \\
\text { No.5 }\end{array}$ & $\begin{array}{l}\text { Identity to } \\
\text { No.6 }\end{array}$ & $\begin{array}{l}\text { Identity to } \\
\text { No.7 }\end{array}$ \\
\hline IBV/Eg/CLEVB-2 & JX173488 & Egypt & 2012 & $65 \%$ & $65 \%$ & $66 \%$ & $66 \%$ & $66 \%$ & $66 \%$ & $67 \%$ \\
\hline IS-1494-06 & EU780077 & Israel & 2006 & $88 \%$ & $88 \%$ & $89 \%$ & $89 \%$ & $88 \%$ & $89 \%$ & $89 \%$ \\
\hline IS-885 & AY279533 & Israel & $r \ldots r$ & $82 \%$ & $82 \%$ & $82 \%$ & $82 \%$ & $81 \%$ & $81 \%$ & $82 \%$ \\
\hline $\mathrm{Eg} / 12120 \mathrm{~s} / 2012$ & KC533684 & Egypt & 2012 & $69 \%$ & $68 \%$ & $69 \%$ & $69 \%$ & $69 \%$ & $69 \%$ & $69 \%$ \\
\hline $\mathrm{Eg} / 1265 \mathrm{~B} / 2012$ & KC533682 & Egypt & 2012 & $65 \%$ & $64 \%$ & $65 \%$ & $66 \%$ & $65 \%$ & $65 \%$ & $66 \%$ \\
\hline QXIBV & AF193423 & China & 1999 & $76 \%$ & $77 \%$ & $78 \%$ & $77 \%$ & $77 \%$ & $77 \%$ & $78 \%$ \\
\hline Egypt-F-03 & DQ487085 & Egypt & 2003 & $72 \%$ & $72 \%$ & $73 \%$ & $73 \%$ & $72 \%$ & $73 \%$ & $73 \%$ \\
\hline CR88121 & JN542567 & France & 2011 & $81 \%$ & $82 \%$ & $83 \%$ & $82 \%$ & $82 \%$ & $82 \%$ & $83 \%$ \\
\hline H120 & M21970 & Netherlands & 1989 & $71 \%$ & $71 \%$ & $72 \%$ & $72 \%$ & $71 \%$ & $72 \%$ & $73 \%$ \\
\hline UK4-91 & AF093794 & United Kingdom & 1998 & $80 \%$ & $80 \%$ & $81 \%$ & $81 \%$ & $80 \%$ & $81 \%$ & $81 \%$ \\
\hline Ma5 & AY561713 & USA & 199. & $72 \%$ & $72 \%$ & $73 \%$ & $73 \%$ & $72 \%$ & $73 \%$ & $73 \%$ \\
\hline M41 & AY561711 & USA & 2004 & $70 \%$ & $69 \%$ & $70 \%$ & $71 \%$ & $70 \%$ & $70 \%$ & $71 \%$ \\
\hline D274 & X15832 & Neterlands & 1989 & $90 \%$ & $90 \%$ & $91 \%$ & $91 \%$ & $89 \%$ & $91 \%$ & $91 \%$ \\
\hline
\end{tabular}


As a result of few changes in the amino acid structure of the $S 1$ protein, new IBV genotypes have usually emerged [23]. Such changes could be attributed to the immune pressure caused by the misuse of multiple types of vaccines or emergence of new strains as a result of mutation and recombination [24].

The nucleotide identity between the seven Damietta Governorate IBV field isolates was ranged from $94 \%$ to $100 \%$ with each other, while, the similarity with the vaccine strains used in Egypt (M41, H120, Ma5, 4/91, CR88 and D274) ranged from $67 \%$ to $71 \%, 69 \%$ to $73 \%, 69 \%$ to $73 \%, 77 \%$ to $81 \%, 78 \%$ to $83 \%$ , $87 \%$ to $91 \%$, respectively. Mutation, recombination and strong positive selection in vivo could explain the diversity in S1 [25]. In addition, changes in few amino acids in the spike (S) glycoprotein might result in the generation of genetic variants of IBV.

Circulation of Egyptian IBV variants among vaccinated and non-vaccinated flocks results in severe economic problems [26]. Thus, indicating partial protection after vaccination with a live attenuated heterologous strain [27].

\section{Conclusion}

In conclusion, IBV still circulating in Egyptian flocks causing high economic losses in broilers, Continuous surveillance of IBV strains in Egypt is essential in defining ideal control procedures, including the choice of the appropriate vaccine strains and vaccination programs.

\section{Conflict of interest}

None of the authors have any conflict of interest to declare.

\section{References}

[1] Cook, J.K.A. (1995) Epidemiology of Infectious Bronchitis Virus, in The Coronaviridae, S.G. Siddell, Editor., Plenum Press: New York. p. 317-335.

[2] Cavanagh D., Naqi S. (1997): Infectious Bronchitis. In: Calnek BW, Barnes HJ, Beard CW. Diseases of poultry. $10^{\text {th }} \mathrm{ed}$.
Ames: Iowa State University Press; p.511-526.

[3] Boursnell, M.E.; Brown, T.D.; Foulds, I.J.; Green, P.F.; Tomley, F.M. and Binns, M.M. (1987): Completion of the sequence of the genome of the coronavirus avian infectious bronchitis virus. J Gen Virol, 68(1):57-77.

[4] Sutou, S.; Sato, S.; Okabe, T.; Nakai, M. and Sasaki, N. (1988): Cloning and sequencing of genes encoding structural proteins of avian infectious bronchitis virus. Virology 165(2): 589-595.

[5] Cavanagh, D. (1995): The coronavirus surface glycoprotein. In: The Coronaviridae. S. G. Siddel, ed. Plenum press, New York. pp 73-103

[6] Spaan, W.; Cavanagh, D. and Horzinek, M.C. (1988): Coronaviruses: structure and genome expression. J Gen Virol, 69(12): 2939-2952.

[7] Lai, M. M., and Holmes, K. V. (2001): Coronaviridae: The viruses and their replication. In: FieldsVirology, 4th ed, D. M. Knipe, P. M. Howley, D. E. Griffin, R. A. Lamb, M. A. Martin, B.Roizman and S. E. Straus, eds. Vol. 1. Lippincott Williams \& Wilkins. pp. 1163-1185.

[8] Cavanagh, D.; Davis, P. J.; Pappin, D. J.; Binns, M. M.; Boursnell M. E.; and Brown, T. D. (1986): Coronavirus IBV: Partial amino terminal sequencing of spike polypeptide $\mathrm{S} 2$ identifies the sequence Arg-Arg-Phe-Arg-Arg at the cleavage site of the spike precursor propolypeptide of IBV strains Beaudette and M41. Virus Res, 4:133-143.

[9] Cavanagh, D.; Davis, P.J. and Mockelt, A.P. (1988): Amino acids with hypervariable region 1 of avian coronavirus IBV (Massachusetts serotype) spike glycoprotein are associated with neutralization epitops. Virus Res, 11(2):141-150.

[10] Koch, G.; Hartog, L.; Kant, A. and Van Roozelaar, D.J. (1990): Antigenic 
domains on the peplomer protein of avian infectious bronchitis virus: Correlation with biological functions. J Gen Virol, 71(9): 1929-1935.

[11] Jackwood, M. W., Kwon, H. M. and Hilt, D. A. (1992): Infectious bronchitis virus detection in allantoic fluid using the polymerase chain reaction and aDNA probe. Avian Dis, 36: 403-409.

[12] Moore, K.M.; Jackwood, M.W. and Hilt, D.A. (1997): Identification of amino acids involved in a serotype and neutralization specific epitope within the s1 subunit of avian infectious bronchitis virus. Arch Virol, 142(11): 2249-2256.

[13] Stern, D.F. and Sefton, B.M. (1982): Coronavirus proteins: structure and function of the oligosaccharides of the avian infectious bronchitis virus glycoproteins. J Virol, 44(3):804-812.

[14] Selim, K.; Arafa, A.; Hussein, H.A. and El-Sanousi, A.A. (2013): Molecular characterization of infectious bronchitis viruses isolated from broiler and layer chicken farms in Egypt during 2012- Int J Vet Science Med, 1(2): 102-108.

[15] Callison, S. A.; Jackwood, M. W. and Hilt, D. A. (2001): Molecular characterization of infectious bronchitis virus isolates foreign to the United States and comparison with United States isolates. Avian Dis, 45(2): 492-499.

[16] Office International Des Epizooties (OIE), Manual of Diagnostic Tests and Vaccines for Terrestrial Animals. Sixth Edition, 2008 Avian Infectious Bronchitis, [Chapter 2.3.2], p. 443-455

[17] Pohuang, T.; Chansiripornchai, N.; Tawatsin, A. and Sasipreeyajan, J. (2009): Detection and molecular characterization of infectious Bronchitis virus isolated from recent outbreaks in broiler flocks in Thailand. J Vet Sci, 10(3): 219-223

[18] Adznar, A.K.; Cough, R.E.; Haydon, D.; Shaw, K.; Britton, P. and Cavangh, D.
(2007): Molecular analysis of the 793/B serotype of IBV in Great Britain. Avian Pathol, 26(3):625-640

[19] Thompson, J.D.; Higgins, D.G. and Gibson, T.J..(1994): CLUSTAL W: improving the sensitivity of progressive multiple sequence alignment through sequence weighting, position-specific gap penalties and weight matrix choice. Nucleic Acids Res, 22(22): 4673-4680.

[20] Tamura, K.; Peterson, D.; Peterson, N.; Stecher, G.; Nei, M. and Kumar, S. (2011): MEGA5: molecular evolutionary genetics analysis using maximum likelihood, evolutionary distance, and maximum parsimony methods. Mol Biol Evol, 28(10):2731-2739.

[21] Cook, J.K.; Darbyshire, J.H. and Peters, R. W. (1976): The use of chicken tracheal organ culture for the isolation and assay of avian infectious bronchitis. Arch Virol, 50(1-2): 109-118.

[22] Cavanagh, D. and Gelb, J. (2008): Infectious bronchitis. In Y.M. Saif, A.M. Fadly, J.R. Glisson, L.R. McDougald, L.K. Nolan \& D.E. Swayne (Eds.). Diseases of Poultry 12th edn (pp. 117_135). Ames, Iowa, USA: Blackwell Publishing Professional.

[23] Cavanagh, D.; Davis, P.J.; Cook, J.K.A.; Li, D.; Kant, A. and Koch, G. (1992): Location of the amino-acid differences in the S1 spike glycoprotein subunit of closely related serotypes of infectious bronchitis virus. Avian Pathol, 21(1):3343.

[24] Liu, S. and Kong, X. (2004): A new genotype of nephropathogenic infectious bronchitis virus circulating in vaccinated and non-vaccinated flocks in China. Avian Pathol, 33(3): 321-327.

[25] Abdel-Moneim, A.S.; El-Kady, M.F.; Ladman, B.S.; and Jack Gelb, Jr. (2006): $\mathrm{S} 1$ gene sequence analysis of a nephropathogenic strain of avian infectious bronchitis virus in Egypt. Virol J, 3:78. 
[26] Susan, S.; El-Hady, M.M. and Soliman, Y.A. (2010): Isolation and characterization of Nephropathogenic strain of infectious Bronchitis virus in Egypt. J American Sci, 6 (9):669-674.

[27] Liu, S.W.; Zhang, X.N.; Wan, Y.; Li, C.G.; Liu, Q.; Han, Z.X.; Zhang, Q.X.;
Kong, X.G. and Tong, G.Z. (2009): Evaluation of the protection conferred by commercial vaccines an attenuated heterologous isolates in China against the $\mathrm{CK} / \mathrm{CH} / \mathrm{LDL} / 971$ strain of infectious bronchitis coronavirus. Vet J, 179(1):130-136.

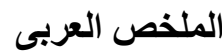

$$
\begin{aligned}
& \text { دراسات جزيئية على فيروس التهاب الثبب الهوائية المعدي فى بدارى التسمين فى محافظة دمياط } \\
& \text { السيد محسن عوض'"، عبد الستار عرفة محمحّ، ايمن هانئ الديب"، أحمد عبد الغني السنوسيَ }
\end{aligned}
$$

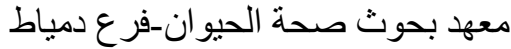

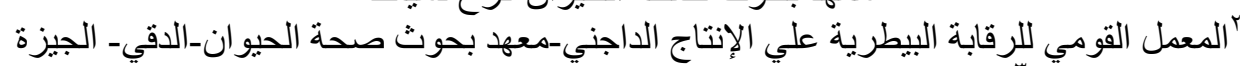

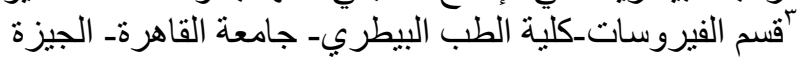

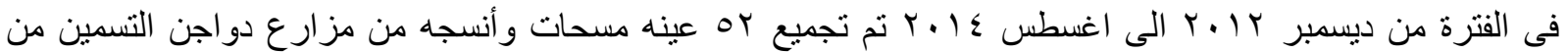

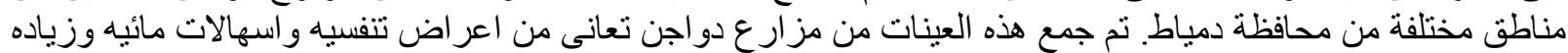

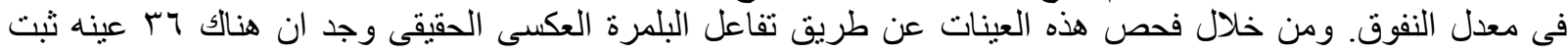

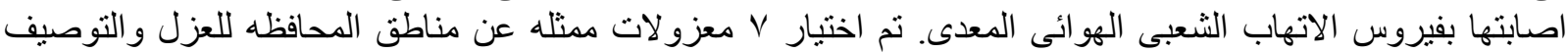

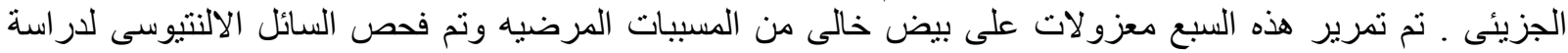

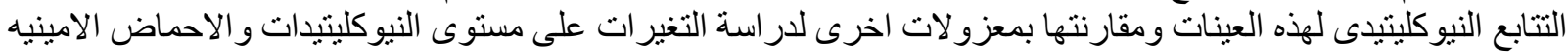

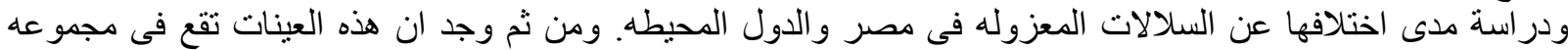

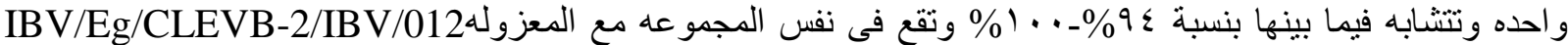

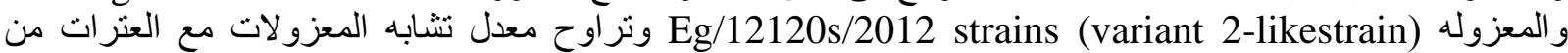

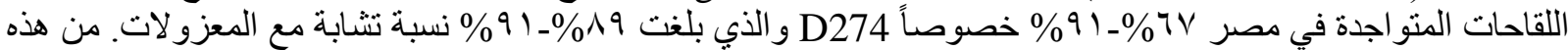
الدراسة نخلص الي ان هناك تعقيدات للتحكم في مرض التهاب الثُب المعدي في ظل اللقاحات المستخدمة حالياً ضد لـد

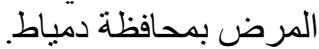

